\title{
Effect of green propolis addition to physical- mechanical properties of glass ionomer cements
}

\author{
Valéria Barros Pereira Barbosa TROCA ${ }^{1}$, Karen Barros Parron FERNANDES ${ }^{2}$, Amélia Elena TERRILE ${ }^{3}$, Maria Cristina \\ MARCUCCI ${ }^{4}$, Flaviana Bombarda de ANDRADE ${ }^{5}$, Linda WANG ${ }^{5}$ \\ 1- MSc, University of North Paraná, Londrina, PR, Brazil. \\ 2- DDS, MSc, PhD, Assistant Professor, Department of Operative Dentistry, School of Dentistry, University North of Paraná, Londrina, PR, Brazil. \\ 3- MSc, Assistant Professor, University Technologic Federal of Paraná, Londrina, PR, Brazil. \\ 4- MSc, PhD, Assistant Professor, University of Bandeirantes, São Paulo, SP, Brazil. \\ 5- DDS, MSc, PhD, Assistant Professor, Department of Operative Dentistry, Endodontics and Dental Materials, Bauru School of Dentistry, University of São \\ Paulo, Bauru, SP, Brazil.
}

Corresponding address: Profa. Dra. Linda Wang - Faculdade de Odontologia de Bauru - USP - Departamento de Dentística, Endodontia e Materias Dentários Disciplina de Dentística - Alameda Octávio Pinheiro Brisolla, 9-75 - 17012-901 - Bauru, SP - Brasil - Phone: +55-14-3235-8325 - FAX: +55-14-3235-8323 e-mail: wang.linda@usp.br

Received: June 22, 2009 - Modification: April 30, 2010 - Accepted: September 9, 2010

\section{ABSTRACT}

$\mathrm{O}$ bjective: This study investigated the mechanical properties of glass ionomer cements (GICs) combined with propolis as a natural antimicrobial substance. Material and Methods: Typified green propolis, as an ethanolic extract (EEP) or in the lyophilized form (powder), was incorporated to specimens of Ketac Fil Plus, ChemFlex and Ketac Molar Easymix GICs. For each test, 8 specimens of each material were prepared. For water sorption and solubility tests, specimens were subjected to dehydration, hydration and redehydration cycles until a constant mass was obtained for each step. Measurements were recorded using a digital balance of $10^{-4} \mathrm{~g}$ precision. For the diametral tensile strength test, specimens were tested in a universal test machine at $0.5 \mathrm{~mm} / \mathrm{min}$ crosshead speed after $24 \mathrm{~h}$ storage in deionized water. Data were evaluated by one-way ANOVA and Tukey's tests $(p<0.05)$. Results: The addition of propolis to GIC clearly increased water sorption compared to pure material. Solubility was material-dependent and was not clearly evident. For the diametral tensile strength test, association with propolis altered negatively only Chemflex. Conclusion: It may be concluded that incorporation of propolis to GICs alters some properties in a material-dependent condition.

Key words: Glass ionomer cements. Propolis. Solubility. Tensile strength.

\section{INTRODUCTION}

Currently, new approaches, techniques and materials have focused on maximum prevention and minimally invasive procedures in Dentistry. According to this philosophy, Atraumatic Restorative Treatment (ART) consists on the removal of carious tissue with hand instruments and restoration with an adhesive material ${ }^{8,28}$. Glass ionomer cement (GIC) is the material of choice as it presents several benefits, mainly adhesion to dental substrates, fluoride release, recharge ability and reverse potential to reduce acidic environment ${ }^{3}$. GIC has also satisfactory biocompatibility and antimicrobial potential, which make this material attractive ${ }^{5}$.

Due to this antimicrobial property the association of known antimicrobial substances, such as propolis, chlorhexidine and antibiotics to GICs has been extensively investigated $7,12,23,30$. In specially challenging clinical situations as in ART, it can be of great interest.

Propolis is a natural resinous substance produced by honey bees ${ }^{9,20}$. Bees extract it from plants exudates, which they process by using an enzyme found in their salivary glandules. The defense of plants against microorganisms explains the antimicrobial effect of propolis $^{9}$. Propolis can vary extensively according to the origin and composition ${ }^{14,15,25}$. It may be typified, in a process in which all components are chemically analyzed. Through this process, bioactive components are identified from original samples to be well applied ${ }^{14}$. 
Diverse biological properties have been proven namely antimicrobial, antiinflammatory, anesthetic and healing actions $s^{6,15,19}$. There are different forms of propolis, such as ethanolic and lyophilized. In scientific papers, the ethanolic extract of propolis (EEP) is the most commonly used, where ethanol works as a solvent or vehicle. Often, EEP is directly employed, resulting in effective antimicrobial potential22.

Despite these benefits, there are only few reports about the addition of propolis to $\mathrm{GIC}^{7,19,30}$. These investigations have focused on antimicrobial effects, but physical-mechanical properties have been overlooked $^{12,22}$. Additionally, propolis application in Dentistry is mostly related to the use of EEP. There is a lack of reports on the use of the lyophilized form, which has been shown to have antibacterial, antiviral, analgesic and regeneration properties ${ }^{24}$.

This study aimed at investigating the effect of 2 different forms of typified green propolis, EEP and lyophilized (L), associated with one conventional GIC and two high-density GICs, regarding mechanical properties. The null hypothesis was that there is no difference in material performance (water sorption, solubility, and diametral tensile strength test), with or without propolis.

\section{MATERIAL AND METHODS}

Propolis was obtained from typified pure extract of green propolis by high-efficiency liquid chromatography as presented in Figure $1^{14}$. The tested GICs (all shade A3) are presented in Figure 2. Each material solvated in ethanol was qualified as its abbreviation followed by $\mathrm{E}$, being $\mathrm{KPE}, \mathrm{CE}$ and $\mathrm{KME}$, while in lyophilized form they were followed by $L$, being, $K P L, C L$ and $K M L$.

\section{Water sorption and solubility}

Eight specimens of each GIC were prepared in 3 different conditions: pure, associated to EEP or to lyophilized form, totalizing 72 samples. This test was conducted according to ISO 4049:1988 ${ }^{11}$. Powder and liquid were measured using a digital balance of $10^{-4} \mathrm{~g}$ precision (Tel Marke; Bel Quimis, São Paulo, SP, Brazil). After manual handling, the mixture was inject into previously isolated steel stainless moulds (15 mm x $0.5 \mathrm{~mm}$ ) using Centrix syringe (Centrix, Centrix Dental, Shelton, CT, USA). A cellophane sheet was used to cover the inserted material. Digital pressure was exerted using a microscope glass slide for $20 \mathrm{~s}$. After $15 \mathrm{~min}$, specimens were removed from mould and lateral excess was removed using a \#15 scalpel blade (Bard-Parker, Flanklin Lakes, NJ, USA). For EEP groups (E) preparation, it was added to GIC-liquid using a pipette (Gilson, Roissy Ch de Gaulle Cedex, France) to obtain a final concentration of $1 \%$ of propolis into $\mathrm{GIC}^{3}$. To prepare specimens using lyophilized propolis (L), it was added to GIC powder reaching a final concentration of $2 \%$.

Specimens were stored in desiccators at $37^{\circ} \mathrm{C}$ containing silica gel. The discs were weighed daily and the complete cycle was repeated until a constant mass $\left(m_{1}\right)$ be obtained, i.e., until the mass loss of each specimen was not more than $0.1 \mathrm{mg}$ per 24-h cycle. The thickness of each specimen was measured at 4 points using an electronic digital caliper (Mitutoyo Corporation, Tokyo, Japan). Thereafter, the specimens were stored in water at $37^{\circ} \mathrm{C}$ for 7 days ( $6 \mathrm{~mL}$ of water per specimen). The specimens were daily reweighed, after being carefully wiped with an absorbent paper. When constant weight was obtained, this value was recorded as $m_{2}$. After this weighing, the specimens returned to the desiccators, the entire mass reconditioning cycle was repeated and the constant mass was recorded as $m_{3}$.

The values for water sorption and solubility, in micrograms per cubic millimeter, were calculated using the following equations: $S=\left(M_{2}-M_{3} / V\right)$ and $\mathrm{SB}=\left(\mathrm{M}_{1}-\mathrm{M}_{3} / \mathrm{V}\right)$. Data were subjected to one-way analysis of variance (ANOVA) and Tukey's test for multiple comparisons $(P<0.05)$.

\section{Diametral Tensile Strength test}

Eight specimens for each group were prepared with dimensions of $6 \mathrm{~mm}$ diameter $\times 3 \mathrm{~mm}$ high. After $1 \mathrm{~h}$, the specimens were individually immersed in deionized water in plastic vials for $24 \mathrm{~h}$. Diametral tensile strength (DTS) was performed using a universal test machine (Kratos Equipamentos Industriais Ltda, Cotia, SP, Brazil) at a crosshead speed $0.5 \mathrm{~mm} / \mathrm{min}$. It was calculated using the equation: $2 \mathrm{P} /=\pi \mathrm{DT}$, where: $\mathrm{P}=$ load applied; $\mathrm{D}=$ diameter of the cylinder, $\mathrm{T}=$ thickness of the cylinder, $\pi=$ (constant) 3.14. DTS values $\left[\mathrm{kgf} / \mathrm{cm}^{2}\right]$ were converted into MPa as follows: DTS[MPa]=DTS[Kgf/ $\left.\mathrm{cm}^{2}\right] \times 0.09807$. Data were subjected to ANOVA and Tukey's tests for individual comparisons at 0.05 level of significance.

\section{RESULTS}

KM showed the least water sorption and KFL the greatest water sorption, with mean values varying from 101.0 to $189.6 \mu \mathrm{g} / \mathrm{mm}^{3}$ (Table 1 ). GICs associated with lyophilized propolis or EEP showed significantly more water sorption than each pure group $(P<0.05)$. The lyophilized form promoted greater water sorption in comparison to groups with EEP. KF presented less water sorption than C, and was not statistically different from KM, both indicated for ART. Thus, the null hypothesis that there is no difference of water sorption among GICs with or without propolis was rejected.

$\mathrm{CL}$ presented the least water solubility whereas $\mathrm{KFL}$ presented the highest solubility, varying from 


\begin{tabular}{|c|c|c|}
\hline Number & Compounds & Sample BRP1 (mg/g) \\
\hline 1 & 6-Propenoic-2,2-dimethyl-8-prenyl-2H-1-benzopiran acid & 12.61 \\
\hline 2 & 3,5-Diprenyl-4-hydroxycinnamic acid (ARTEPILLIN C ${ }^{\circledR}$ ) & 29.50 \\
\hline 3 & 3,5-Diprenyl-4-hydroxycinnamic acid* (derivative 1) & 0.94 \\
\hline 4 & 3,5-Diprenyl-4-hydroxycinnamic acid* (derivative 2) & 2.52 \\
\hline 5 & 3,5-Diprenyl-4-hydroxycinnamic acid* (derivative 3) & 1.21 \\
\hline 6 & 3,5-Diprenyl-4-hydroxycinnamic acid* (derivative 4) & 0.98 \\
\hline 7 & 3,5-Diprenyl-4-hydroxycinnamic acid* (derivative 5) & 1.34 \\
\hline 8 & 3,5-Diprenyl-4-hydroxycinnamic acid* (derivative 6) & 1.37 \\
\hline 9 & 3,5-Diprenyl-4-hydroxycinnamic acid* (derivative 7) & 6.37 \\
\hline 10 & 3,5-Diprenyl-4-hydroxycinnamic acid* (derivative 8) & 3.55 \\
\hline 11 & 3,5-Diprenyl-4-hydroxycinnamic acid* (derivative 9) & 0.41 \\
\hline 12 & 3-Prenyl-4-hydroxycinnamic acid & 6.51 \\
\hline 13 & Caffeic acid & 1.70 \\
\hline 14 & Caffeoylquinic acid $1^{* *}$ & 2.58 \\
\hline 15 & Caffeoylquinic acid $1^{* *}$ & 1.05 \\
\hline 16 & Caffeoylquinic acid $1^{* *}$ & 10.16 \\
\hline 17 & Caffeoylquinic acid $1^{* *}$ & 16.34 \\
\hline 18 & Caffeoylquinic acid $1^{* *}$ & 0.83 \\
\hline 19 & Cinnamic acid $^{* * *}$ (derivative 1 ) & 9.33 \\
\hline 20 & Cinnamic acid ${ }^{* * *}$ (derivative 1$)$ & 2.35 \\
\hline 21 & Cinnamic acid ${ }^{* * *}$ (derivative 1 ) & 65.05 \\
\hline 22 & p-Coumaric acid & 14.56 \\
\hline 23 & Kaempferide & 21.88 \\
\hline 24 & Kaempferol & 2.51 \\
\hline \multirow[t]{3}{*}{25} & Pinobanksin & 33.21 \\
\hline & Total (mg/g of propolis in natura) & 254.57 \\
\hline & Total $(\%)(\mathrm{m} / \mathrm{m})$ & 25.46 \\
\hline
\end{tabular}

* Same UV spectrum of 3,5-Diprenyl-4-hydroxycinnamic acid, with different retention time. Expressed in 3,5-Diprenyl-4hydroxycinnamic acid

** Same UV spectrum of Caffeic acid, with different retention time. Expressed in Caffeic acid

*** Same UV spectrum of Cinnamic acid, with different retention time. Expressed in Cinnamic acid Source: Marcucci'14 (2000).

Figure 1- Amount of each identified component by high-efficiency liquid chromatography analysis of in natura propolis

-50.56 to $1.25 \mu \mathrm{g} / \mathrm{mm}^{3}$ (Table 2). Except for $\mathrm{KFL}$, all GICs showed negative values of solubility. For $\mathrm{KF}$, there was no difference among the subgroups of this product. For KM groups, both associations of the GIC with propolis showed greater solubility compared to control group $\mathrm{KM}$; however, $\mathrm{KML}$ did not differ significantly from KM and KME. CE and $C$ demonstrated significantly greater solubility in water compared to $\mathrm{CL}$. KF reached higher values of solubility in water when compared to $C$ and $\mathrm{KM}$, both indicated to ART. Data revealed distinct performances among tested materials and solubility was material-dependent. The null hypothesis that there is no difference in water solubility of GICs with or without propolis is partially accepted.

KME showed the lowest DTS and C the highest DTS, varying from 7.74 to $18.77 \mathrm{MPa}$ (Table 3). When GICs were not associated with any kind of propolis, DTS reached the highest values compared to GIC-propolis groups. C demonstrated the highest value with significant differences from all groups, except for KF with the second highest DTS means. $\mathrm{KM}$ was less resistant to $\mathrm{KFL}$, which reached the third greatest resistance under DTS test. Only C was significantly higher to its propolis-associated counterparts. KF was not significantly different from $\mathrm{C}$ and $\mathrm{KM}$. Propolis form seems not to influence differently each tested GIC. As the performance 


\begin{tabular}{|c|c|c|c|c|c|}
\hline $\begin{array}{l}\text { Products/ } \\
\text { Abreviation }\end{array}$ & Manufacturer & Composition* & Classification & Lot/ Expiry & $\begin{array}{c}\text { Weight } \\
\text { Proportion P/L }\end{array}$ \\
\hline $\begin{array}{l}\text { Ketac Molar } \\
\text { Easymix } \\
(\mathrm{KM})\end{array}$ & $\begin{array}{c}\text { 3M ESPE, Dental } \\
\text { Products, St. Paul, } \\
\text { MN, USA }\end{array}$ & $\begin{array}{l}\text { Power: Calcium aluminum } \\
\text { lanthan fluorosilicate glass, } \\
\text { copolymer, pigments } \\
\text { Liquid: Acrylic acid, maleic } \\
\text { acid copolymer, tartaric } \\
\text { acid, benzoic acid }\end{array}$ & $\begin{array}{l}\text { High-density } \\
\text { GIC }\end{array}$ & $\begin{array}{l}\text { Power: } 12.5 \mathrm{~g} \\
223626 \\
(04 / 2007) \\
\text { Liquid: } 8.5 \mathrm{~mL} \\
212425 \\
(06 / 2007)\end{array}$ & 2.9:1.0 \\
\hline $\begin{array}{c}\text { ChemFlex@ } \\
\text { (C) }\end{array}$ & $\begin{array}{l}\text { DENTSPLY, Rio de } \\
\text { Janeiro, RJ, Brazil }\end{array}$ & $\begin{array}{c}\text { Power: Estrontium } \\
\text { fluoraluminium silicate } \\
\text { glass } \\
\text { Liquid: Poliacrylic acid, } \\
\text { tartaric acid, pigments }\end{array}$ & $\begin{array}{l}\text { High-density } \\
\text { GIC }\end{array}$ & $\begin{array}{c}\text { Power: } 15 \mathrm{~g} \\
0503001430 \\
(03 / 2008) \\
\text { Liquid: } 6 \mathrm{~mL} \\
0412000907 \\
(10 / 2007)\end{array}$ & 3.8:1.0 \\
\hline $\begin{array}{c}\text { Ketac Fil Plus } \\
(\mathrm{KF})\end{array}$ & $\begin{array}{c}\text { 3M ESPE, Dental } \\
\text { Products, St. Paul, } \\
\text { MN, USA }\end{array}$ & $\begin{array}{c}\text { Power: Calcium aluminum } \\
\text { lanthan fluorosilicate glass, } \\
\text { strontium. } \\
\text { Liquid: Water, acrylic an } \\
\text { maleic acids copolymer, } \\
\text { tartaric acid and benzoic } \\
\text { acid }\end{array}$ & $\begin{array}{l}\text { Conventional } \\
\text { GIC }\end{array}$ & $\begin{array}{c}\text { Power: } 10 \mathrm{~g} \\
254776 \\
(06 / 2009) \\
\text { Liquid: } 8.3 \mathrm{~mL} \\
255496 \\
(07 / 2009)\end{array}$ & $3.2: 1.0$ \\
\hline
\end{tabular}

Figure 2- Materials tested

Table 1- Means (standard errors) of water sorption

\begin{tabular}{lcllll}
\hline Material & Water Sorption $\left(\mu \mathrm{g} / \mathrm{mm}^{3}\right)$ & & & \\
\hline & $\left(\mu \mathrm{g} / \mathrm{mm}^{3}\right)$ & & & \\
KFL & $189.6(9.75)$ & $\mathrm{A}$ & & \\
$\mathrm{CL}$ & $186.6(4.81)$ & $\mathrm{A}$ & & \\
$\mathrm{CE}$ & $177.0(4.60)$ & $\mathrm{A}$ & & \\
KML & $153.8(2.93)$ & & B & \\
KME & $148.3(3.09)$ & & B & \\
C & $146.4(2.78)$ & & B & C & \\
KFE & $125.0(1.40)$ & & & C & \\
KF & $114.8(6.50)$ & & & D \\
KM & $101.0(2.55)$ & & & D \\
\hline
\end{tabular}

Different letters indicate statistically significant differences among materials $(P<0.05)$. $L=$ lyophilized; $E=$ ethanolic extract of propolis

was material-dependent, the null hypothesis that there is no difference on the DTS of the GICs with or without propolis was partially accepted.

\section{DISCUSSION}

Dentistry has focused on different technologies to develop new materials and approaches to dental restorations ${ }^{2,10}$. With this objective, association of
Table 2- Means (standard errors) of water solubility ( $\mu \mathrm{g} /$ $\mathrm{mm}^{3}$ )

\begin{tabular}{llllllllll}
\hline Material & Solubility $\left(\mu \mathrm{g} / \mathrm{mm}^{3}\right)$ & & & & & & \\
\hline KFL & $1.25(9.61)$ & A & & & & & & \\
KF & $-10.32(1.15)$ & A & B & & & & & \\
KFE & $-14.39(2.24)$ & A & B & C & & & & \\
KME & $-16.13(3.03)$ & A & B & C & D & & & \\
CE & $-19.74(2.35)$ & & B & C & D & E & & \\
C & $-24.31(5.44)$ & & B & C & D & E & F & \\
KML & $-30.76(2.05)$ & & & C & D & E & F & \\
KM & $-42.28(1.15)$ & & & & & & F & G \\
CL & $-50.56(2.85)$ & & & & & & & G \\
\hline
\end{tabular}

Different letters indicate statistically significant differences among materials $(P<0.05) . L=$ lyophilized; $E=$ ethanolic extract of propolis

available materials with different substances has led to a promissory field, but further research has to be done to allow this actual application. Following this rationale, propolis as an easy available natural substance seems to be a great option for dental treatment. However, few studies still reported this ${ }^{19,30}$. Due to their relevant antimicrobial features, conventional GIC is the material of choice to caries high-risk patients ${ }^{27,28}$. Since the introduction of the ART approach, high-density materials with 
Table 3- Means (standard errors) of diametral tensile strength (MPa)

\begin{tabular}{|c|c|c|c|}
\hline Material & Diametral te & gth & $M P$ \\
\hline$C$ & $18.77(2.34)$ & A & \\
\hline KF & $17.33(1.97)$ & A & B \\
\hline KFL & $12.90(0.85)$ & & B \\
\hline KM & $12.46(0.62)$ & & B \\
\hline CE & $11.94(0.82)$ & & B \\
\hline$C L$ & $10.76(0.76)$ & & B \\
\hline KML & $9.57(0.76)$ & & B \\
\hline KFE & $8.10(0.82)$ & & B \\
\hline KME & $7.74(0.56)$ & & D \\
\hline
\end{tabular}

Different letters indicate statistically significant differences among materials $(P<0.05)$. $L=$ lyophilized; $E=$ ethanolic extract of propolis

conventional setting have been introduced in order to clinically serve in more stressful areas as posterior teeth ${ }^{27,28}$. Although these materials have a conventional setting, their high density could influence the capacity of propolis to affect these materials and so they were included in the present study.

As GIC is a hydrophilic material, it is critical under highly moist conditions. Water plays an important role on the physical-mechanical properties of GICs as they are based on an acid-base reaction ${ }^{17}$. GICs restorations are susceptible to gain and loss of water, making superficial protection a relevant procedure ${ }^{4}$. In the present study, no protection was made to test the maximum potential of each material under water critical storage.

Analyses of water sorption revealed values from 101.0 to $189.6 \mu \mathrm{g} / \mathrm{mm}^{3}$, which are in agreement with previously reported investigations ${ }^{4,5,17}$. Cefaly, et $a^{5}{ }^{5}$ (2003) evaluated water sorption of highdensity viscosity GICs used in ART and found means of $137.66 \mu \mathrm{g} / \mathrm{mm}^{3}$ (Fuji IX), $100.97 \mu \mathrm{g} / \mathrm{mm}^{3}$ (Ketac Molar) and $120.34 \mu \mathrm{g} / \mathrm{mm}^{3}$ for Ketac Fil Plus, which are similar to the values of water sorption of the present study.

In the present study, groups in which GIC was associated with lyophilized propolis showed greater sorption. Water excess is not clinically desired as it can be detrimental to the physical properties. However, when GICs were associated with EEP, the values were more similar to the control groups, making this option more indicated to be clinically applied. Additionally, it has been to consider that in this test, no superficial protection was performed and this care can reduce this limitation once in a clinical service.

Solubility in water is also a relevant property, as a soluble material can reach pulp tissue through dentinal tubules. If a material presents beneficial characteristics, solubility can be positive; on the other hand, toxic products can compromise biological functions of pulp ${ }^{13}$.

The values of the present study ranged from -50.56 to $1.25 \mu \mathrm{g} / \mathrm{mm} 3$. There are different methods to analyze the effect of solubility 1,21 , which impairs the comparison with previous investigations. However, our findings are in accordance with those of Mortier, et al. ${ }^{17}$ (2004).

Except for $\mathrm{KFL}$, all materials showed negative values, which can indicate that these materials suffered water sorption in a level that could have masked the actual solubility in water. It can be explained by the high hydrophilicity of GIC-based materials. Addition of propolis seems to optimize this property.

According to the results of this test, all groups presented solubility similar to that of the respective control groups, which is considered clinically acceptable by previous studies. In laboratory, it was observed evident solubility of both combinations using lyophilized and EEP forms. Water storage presented yellow coloration, which can indicate release of propolis. As propolis is a natural and biocompatible substance ${ }^{15,20}$, its release is clinically interesting acting sinergically to fluoride with anticariogenic properties.

As combination of GIC and propolis has demonstrated alterations, mechanical strength was important to be investigated. DTS is usually applied to test brittle materials as GIC, $4,18,23,29$ and so was properly used in this investigation.

DTS values varied from 7.74 to $18.77 \mathrm{MPa}$, similar results of previous reports ${ }^{4,29}$. Yap, Pek and Cheang ${ }^{29}$ (2003) evaluated high-density GICs with values of 12.27 MPa (Fuji IX GP) and 10.55 MPa (Fuji IX GP Fast) after $24 \mathrm{~h}$ water storage. Except for Chemflex, all tested groups were not statistically different, which indicates that no significant alterations were verified. It suggests that this combination can be applied.

However, some difficulties observed in this study have to be mentioned. Addition of lyophilized propolis led to a hard manipulation. When EEP was added, the opposite was verified. It requires attention to material preparation to obtain the adequate consistency and to not compromise material's properties. Another limitation is attributed to color change of groups in which propolis was associated with GIC. As the material turned into yellow, it could be indicated as base or liner not to compromise restorative color match.

Based on the results of this investigation, the use of propolis combined with GICs is promising, in spite of some limitations. Other types of propolis, such as red one, are getting available presenting successful performance ${ }^{26}$. It would be of particular 
interesting as a resource against caries disease and prevention to secondary caries. However, more studies should be conducted to analyze the potential and risks before clinical use. Other technologies, such as the incorporation of hydroxyapatite and fluorapatite nanobioceramics to GIC are under investigation using ethanol based sol-gel technique and it also seems to be promising ${ }^{18}$. However, these strategies are mostly focused on machanical and not antimicrobial features. All these new data highlight GIC as a dental material with excellent perspectives. Special attention should be directed to the limitation of GICs, as stated by Mjör ${ }^{16}$ (2007), who called the attention to studies investigating their anticariogenic potential, as one of the basic problems is that the release of anticariogenic agent may result in material degradation ${ }^{16}$. Additionally, controlled clinical trials have to be done to verify the correlation to in vitro strength and anticariogenic observations ${ }^{16}$.

The properties evaluated in this study are useful to consider the factors to be further investigated in order to enhance the applicability of combining GIC and propolis in a single product.

\section{ACKNOWLEDGEMENTS}

Authors are grateful to UNOPAR for financial support and Vera Lúcia dos Santos and Dionadir de Almeida for laboratory support. They also thank 3M ESPE and Dentsply Inc. for material donation and Angelus for permission to equipment and laboratory use.

\section{REFERENCES}

1- Bapna MS, Mueller HJ. Relative solubilities of hybrid ionomers and compomers by acid impingement. J Oral Rehabil. 1999;26:78690.

2- Bertolini MJ, Zaghete MA, Gimenes R, Padovani GC. Determination of the properties of an experimental glass polyalkenoate cement prepared from niobium silicate powder containing fluoride. Dent Mater. 2008;24:124-8.

3- Can-Karabulut DC, Batmaz I, Solak H, Taştekin M. Linear regression modeling to compare fluoride release profiles of various restorative materials. Dent Mater. 2007;23:1057-65.

4- Cefaly DFG, Franco EB, Mondelli RFL, Francisconi PAS, Navarro MFL. Diametral tensile strength and water sorption of glass-ionomer cements used in Atraumatic Restorative Treatment. J Appl Oral Sci. 2003;11:96-101.

5- Cefaly DFG, Wang L, Mello LLCP, Santos JL, Santos JR, Lauris JRP. Water sorption of resin-modified glass-ionomer cements photoactivated with LED. Braz Oral Res. 2006;20:342-6.

6- Ferreira FBA, Torres SA, Rosa OPS, Ferreira CM, Garcia RB, Marcucci MC, et al. Antimicrobial effect of propolis and other substances against selected endodontic pathogens. Oral Surg Oral Med Oral Pathol Oral Radiol Endod. 2007;104:709-16.

7- Ferreira HC, Rego MA. Evaluation in vitro of properties physicistchemistries of glass-ionomer cements, after addition of propolis and antibiotics. Ciênc Odontol Bras. 2006;9:38-46.
8- Frencken JE, Pilot T, Songpaisan Y, Phantumvanit P. Atraumatic Restorative Treatment (ART): rationale, technique and development. J Public Health Dent. 1996;56:135-40.

9- Ghisalberti EL. Propolis: a review. Bee World.1979;60:59-84. 10- Hiraishi N, Yiu CK, King NM, Tay FR, Pashley DH. Chlorhexidine release and water sorption characteristics of chlorhexidineincorporated hydrophobic/hydrophilic resins. Dent Mater. 2008;24:1391-9.

11- International Standard Organization. ISO 4049: Dentistry resin based filling materials. Geneva: The Organization; 1988.

12- Jedrychowski JR, Caputo AA, Kerper S. Antibacterial and mechanical properties of restorative materials combined with chlorhexidines. J Oral Rehabil. 1983;10:373-81.

13- Knight GM, McIntyre JM, Craig GG. Electron probe microanalysis of ion exchange of selected elements between dentine and adhesive restorative materials. Austr Dent J. 2007;52:128-32.

14- Marcucci MC. Processo de identificação de tipagens da propolis brasileira. Rio de Janeiro: INPI; 2000.

15- Marcucci MC. Propolis: chemical composition, biological properties and therapeutic activity. Apidologie. 1995;26:83-99.

16- Mjör IA. Minimum requirements for new dental materials. J Oral Rehabil. 2007;34:907-12.

17- Mortier E, Gerdolle DA, Jacquot B, Panighi MM. Importance of water sorption and solubility studies for couple bonding agent resin-based filling material. Oper Dent. 2004;29:669-76.

18- Moshaverinia A, Ansari S, Moshaverinia M, Roohpour N, Darr JA, Rehman I. Effects of incorporation of hydroxyapatite and fluoroapatite nanobioceramics into conventional glass ionomer cements (GIC). Acta Biomater. 2008;4:432-40.

19- Ozan F, Sümer Z, Polat ZA, Er K, Ozan U, Deger O. Effect of mouthrinse containing propolis on oral microorganisms and human gingival fibroblasts. Eur ] Dent. 2007;1:195-201.

20- Paulino N, Teixeira C, Martins R, Scremin A, Dirsch VM, Vollmar $A M$, et al. Evaluation of the analgesic and anti-inflammatory effects of a Brazilian green propolis. Planta Med. 2006;72:899-906.

21- Peez R, Frank S. The physical-mechanical performance of the new Ketac Molar Easymix compared to commercially available glass ionomer restoratives. J Dent. 2006;34:582-7.

22- Rezende GPSR, Pimenta FC, Costa LRRS. Antimicrobial activity of two brazilian commercial propolis extracts. Braz J Oral Sci. 2006;5:967-70.

23- Sanders BJ, Gregory RL, Moore K, Avery DR. Antibacterial and physical properties of resin modified glass-ionomers combined with chlorhexidine. J Oral Rehabil. 2002;29:553-8.

24- Sosnowski ZM, inventor. Method for extracting propolis and water soluble dry propolis powder. US 4382886. 1983 Oct. 05. 25- Teixeira ÉW, Negri G, Meira RMSA, Message D, Salatino A. Plant origin of green propolis: bee behavior, plant anatomy and chemistry. Evid Based Complement Alternat Med. 2005;2:85-92. 26- Trusheva B, Popova M, Bankova V, Simova S, Marcucci MC, Miorin $\mathrm{PL}$, et al. Bioactive constituents of Brazilian red propolis. Evid Based Complement Alternat Med. 2006;3:249-54.

27- Wang L, Cefaly DFG, Santos JL, Santos JR, Lauris JRP, Mondelli $\mathrm{RFL}$, et al. In vitro interactions between acidic lactic solution and ART glass-ionomer cements. J Appl Oral Sci. 2009;17:274-9. 28- Wang L, Lopes LG, Bresciani E, Lauris JRP, Mondelli RFL, Navarro MFL. Evaluation of Class I ART restorations in Brazilian schoolchildren: three-year results. Spec Care Dentist. 2004;24:2833.

29- Yap AUJ, Pek YS, Cheang P. Physico-mechanical properties of a fast-set highly viscous GIC restorative. J Oral Rehabil. 2003;30:1-8. 30- Yesilyurt C, Er K, Tasdemir T, Buruk K, Celik D. Antibacterial activity and physical properties of glass-ionomer cements containing antibiotics. Oper Dent. 2009;34:18-23. 